\title{
SOCIAL INNOVATION: TOWARDS
}

\section{A NEW INNOVATION PARADIGM}

\section{JÜRGEN HOWALDT}

Doctor from the Faculty of Social Sciences at the University of Bremen. Professor, director from the Sozialforschungsstelle at the TU Dortmund University. Evinger Platz 17, Eving, Dortmund - North rhine-Westphalia - Germany - 44339

E-mail: howaldt@sfs-dortmund.de

\section{DMITRI DOMANSKI}

Master's degree from the Faculty of Social and Behavioural Sciences at the University of Tübingen.

Researcher from the Sozialforschungsstelle at the TU Dortmund University.

Evinger Platz 17, Eving, Dortmund - North rhine-Westphalia - Germany - 44339

E-mail: domanski@sfs-dortmund.de

\section{CHRISTOPH KALETKA}

Doctor in Philosophy from the Department of Communication at the University of Münster. Researcher, management board member from the Sozialforschungsstelle at the TU Dortmund University. Evinger Platz 17, Eving, Dortmund - North rhine-Westphalia - Germany - 44339 E-mail: kaletka@sfs-dortmund.de

This article may be copied, distributed, displayed, transmitted or adapted since the name of the journal, the edition, the year and the pages cited where the article was originally published be clearly and explicitly, but without suggesting that the RAM endorses article reuse. This licensing term must be made explicit for reuse or distribution to third parties. It is not allowed its use for commercial purposes. 


\section{ABSTRACT}

Purpose: Against the backdrop of clear paradoxes and confusion in prevailing innovation policies, the contours of a new innovation paradigm, as elaborated in this paper, are becoming visible and causing social innovation to grow in importance. Originality/gap/relevance/implications: However, innovation research is still lacking sustained and systematic analysis of social innovation, its theories, characteristics, and impacts. The purpose of this paper is to focus on a theoretically sound concept of social innovation as a precondition for an integrated theory of socio-technological innovation in which social innovation is more than an appendage of technological innovation.

Key methodological aspects: The paper presents first empirical results of the global research project "SI-DRIVE: Social Innovation - Driving Force of Social Change" and introduces key findings of a global mapping of social innovation initiatives. This quantitative mapping is based upon I.005 social innovation initiatives.

Summary of key results: The mapping underlines the broad range of actors involved in the mapped initiatives and thereby confirms the need for a crosssectoral concept of social innovation. It reveals a high diversity of social needs and societal challenges addressed by the initiatives as well as a high dependency on networks. The results also show that $90 \%$ of the initiatives are scaling.

Key considerations/conclusions: Finally, on the basis of these empirical results, a recourse to Gabriel Tarde's social theory allows us to widen a perspective which was narrowed to economic and technological innovations by Schumpeter and after him by the sociology of technology, and to include social innovations in all their diversity.

\section{KEYWORDS}

Social innovation. New innovation paradigm. Social change. Global mapping. Gabriel Tarde. 


\section{INTRODUCTION}

Since Schumpeter, the concept of innovation has focused predominantly on economic and technical developments, whereas social sciences were particularly interested in the corresponding social processes and effects (Harrisson, 20I2). This may explain why social sciences, until this day, have been conducting empirical work on social innovations quite comprehensively, but without labelling them as such and, with few exceptions, without a concept of social innovation informed by social theory.

Technological innovations are elements of this continuous process and, due to the predominant patterns of imitation and invention, they have become the centre of attention (Howaldt \& Schwarz, 20I0; Hochgerner, 20I2). They represent a special type of inventions taking the form of artefacts (e.g. machines, computers, cars). The belief in the central role of science and technologies is still the basis for contemporary innovation policies and the discourse on National Innovation Systems.

Meanwhile, the importance of social innovation successfully addressing social, economic, political and environmental challenges of the 2ist century has been recognized not only within the Europe 2020 strategy, but also on a global scale (see the manifold contributions in Harrisson, Bourque, \& Széll, 2009; Franz, Hochgerner, \& Howaldt, 2012 and Moulaert, MacCallum, Mehmood, \& Hamdouch, 20I3a). So, "in recent years, social innovation has become increasingly influential in both scholarship and policy" (Moulaert, MacCallum, Mehmood, \& Hamdouch, 20I3b, p. I). However, despite this growing awareness of the significance of social innovation, there is still no sustained and systematic analysis of social innovation, its theories, characteristics, and impacts. A plethora of vastly diverging subject matters and problem dimensions, as well as expectations for resolving them are subsumed under the heading 'social innovation' without making distinctions between different social and economic meanings, the conditions governing its inception, its genesis and diffusion, and without clearly distinguishing it from other forms of innovation (Jenson \& Harrisson, 20I3).

In light of the increasing importance of social innovation, this paper focuses on a theoretically sound concept of social innovation as a precondition for the development of an integrated theory of socio-technological innovation in which social innovation is more than a mere appendage, side effect and result of technological innovation. Only by taking into account the unique properties and specifics of social innovation, it will be possible to understand the systemic connection and interdependence of social and technological innovation processes and analyse the relationship between social innovation and social change. 
Following the introduction, the paper starts with an overview of the current situation and the perspectives of socio-scientific innovation research which have particularly contributed to the development and spread of an enlightened socioscientific understanding of innovation. Against the backdrop of clear paradoxes and confusion in prevailing innovation policies, the contours of a new innovation paradigm are becoming visible and causing social innovation to grow in importance (see Section 2). The paper reflects upon the relationship between social innovation and social change (Section 3). It then presents the objectives, the concept and first empirical results of the global research project "SI-DRIVE: Social Innovation - Driving Force of Social Change" which intends to extend knowledge about social innovation by integrating theories and research methodologies (Section 4). By these empirical results, a recourse to Gabriel Tarde's social theory (Section 5) allows us to widen a perspective which was narrowed to economic and technological innovations by Schumpeter, and after him by the sociology of technology, and to include social innovations in all their diversity.

\section{CURRENT STATUS AND PERSPECTIVES OF INTERNATIONAL INNOVATION RESEARCH: A NEW INNOVATION PARADIGM}

As a discipline, innovation research widely finds its systematic beginnings and point of reference, valid to this day, in Schumpeter's I9I2 publication of "Theorie der wirtschaftlichen Entwicklung" [Theory of economic development] (Schumpeter, 1964), where a definition of innovation is introduced. According to this work, economic development takes place as a permanent process of "creative destruction". What propels this dynamic, the impetus and origin of economic fluctuation, is innovation in the sense of the "execution of new combinations", of "establishing a new production function". Inventions become innovations if they successfully take hold on the market (diffusion). Introducing and realizing innovations are the actual work and function of the entrepreneurship. Schumpeter focuses not only on technological innovation, but also distinguishes between product-related, procedural and organizational innovations, using new resources, and tapping new markets. He also addresses the process of innovation. Moreover, he underscores the necessity of social innovation occurring in tandem in both the economic arena as well as in culture, politics and society's way of life to guarantee the economic efficacy of technological innovations. 
Following Schumpeter, innovations are increasingly reduced to technological innovations. Remarks on social innovation in literature after Schumpeter are scarce and marginal (Moulaert, Martinelli, Swyngedouw, \& Gonzalez, 2005). From an economics vantage point, involvement with innovation today is directed primarily at the underlying conditions impeding and fostering innovation, both within a company and outside of it, the necessary or deployable resources, the organization of innovation management in terms of systematic innovation replacing or enhancing the role of the entrepreneur (Blättel-Mink, 2006) as well as the economic impact and effects of innovation.

Innovation research in the social sciences has been dedicated, by contrast, primarily to the relevance of innovation's social framework conditions. The central focus is on the social preconditions and influencing factors for (predominantly) technological innovations, the correlation between the technological and the social, between technological and social innovations, between innovations and societal development, the institutional context and the interaction between those involved in the process of innovation. Innovation research in the social sciences has made great contributions to the development and spread of an enlightened sociological understanding of innovation. Its interpretative possibilities have become widely and 'successfully' practical.

From deviation to the norm, from agent to system: this describes the central scientific discourses on innovation characterizing the last Ioo years - always in reaction to the innovation that has actually taken place, seldom, as was the case with Schumpeter, on a proactive basis. (Blättel-Mink, 2006, p. I2).

The central elements of a sociologically enlightened understanding of innovation could be summarized as follows: I. the systematic and social character of innovation that can be not reduced to technological and organizational innovation; 2. aspects of complexity, risk and reflexion; 3 . incompatibility with planning and limited manageability; 4 . an increasing variety and heterogeneity of involved agents; 5. non-linear trajectories as well as a high degree of context and interaction contingency. Consequently, technological and social innovations can be seen as closely intertwined and can only be completely captured in their interaction with one another.

Against the background of the findings in innovation research, the question arises whether the technology-oriented innovation paradigm that has been shaped by the industrial society is not becoming increasingly less functional. This sort of fundamental change process involving the entire institutional structure and the associated way of thinking and basic assumptions can be interpreted, in 
our opinion, in terms of the development of a new innovation paradigm ${ }^{\mathrm{I}}$ (Howaldt $\&$ Schwarz, 20I0). This approach opens up fundamentally new perspectives on recognized problems and thus simultaneously unlocks new possibilities for action. Especially in light of the basic confusions and paradoxes in innovation policy at present, this sort of interpretation of the current changes may open up new perspectives on innovation ${ }^{2}$.

International innovation research is also providing numerous indications of this fundamental shift in the innovation paradigm. In his introduction to the "Oxford Handbook of Innovation", which compiles the key development trajectories of international innovation research, Fagerberg, Mowery and Nelson (2005, p. I4) describe the variability of innovation as one of its central characteristics: "One of the striking facts about innovation is its variability over time and space. It seems, as Schumpeter pointed out, to 'cluster' not only in certain sectors but also in certain areas and time periods". Individual analyses provide descriptions of specific innovation systems in different economic sectors and industries (Malerba, 2005; Von Tunzelmann \& Acha, 2005). At the same time, a vast heterogeneity in innovation can be perceived in terms of the historical development of the process of innovation (Bruland \& Mowery, 2005).

The argument for the thesis of the emergence of a new innovation paradigm is supported by the work of Bruland and Mowery (2005). The authors believe that fundamental changes occur in the structures of innovation systems in different time periods. These changes are described as an expression of different phases of the industrial revolution. When a new innovation system takes hold, it leads to far-reaching changes in the institutional structures. "But both of these episodes highlight the importance of broad institutional change, rather than the 'strategic importance' of any single industry or technology" (Bruland \& Mowery, 2005, p. 375). As such, the "leading industries" (Bruland \& Mowery, 2005, p. 374) have a tremendous influence on the prevailing innovation mode.

In the face of the social shift from an industrial society to knowledge and service economy and the profound change, this entails in the economic and social structures of modern society, there are many indications signalling a fundamental shift in the innovation paradigm that can be detected. New economic sectors and industries are increasingly determining the look of the economy and society and are changing the modes of production and innovation. Challenges such as

Paradigm means, in this sense, borrowing from Kuhn (I996), "a pattern of thought rooted in commonly held basic assumptions that can offer a community of experts considerable problems and solutions for a certain period of time" (Kuhn, I996, p. 26).

2 The authors of a study relating to the OECD Committee for Industry, Innovation, and Entrepreneurship (CIIE) advance this thesis: "A new nature of innovation is emerging and reshaping public policy" (Rosted, Kjeldsen, Bisgaard, \& Napier, 2009). 
ageing population or climate change entail social demands and action, for which traditional ways, in which markets, states, and civil society responded so far, are no longer sufficient. At the same time, technological innovation encounters limitations when it comes to resolving pressing social challenges. The Europe 2020 Strategy, as well as its specific Flagship Initiatives, recognise these challenges. The Flagship Initiative on the Innovation Union clearly stipulates the importance of social innovation to successfully cope with the abovementioned challenges. Similar to the European Commission (EC), many governments of European Member States, other states (e.g. Australia, Canada, China, Colombia, New Zealand, USA) and UN Organisations, acknowledge social innovation as essential to improve future innovation policies ${ }^{3}$. We need a fundamental broadening of perspective. Thus, the Vienna Declaration (2OII, p. 2) states:

The most urgent and important innovations in the 2Ist century will take place in the social field. This opens up the necessity as well as possibilities for Social Sciences and Humanities to find new roles and relevance by generating knowledge applicable to new dynamics and structures of contemporary and future societies.

At the heart of the industrial society innovation paradigm were technological innovations (relating to products and processes) that were regarded as almost the only hope of societal development (Gillwald, 2000). At the same time, social innovations, despite their importance, were largely ignored as a topic and used to be are a little-recognized phenomenon (Gillwald, 2000). With social innovations, the new does not manifest itself in the medium of technological artefacts, but at the level of social practices. If it is accepted that the invention and diffusion of the steam engine, the computer or the smartphone should be regarded differently from the invention and social spread of a national system of healthcare provision, the concept of corporate social responsibility (CSR) or a system of micro financing, then it stands to reason that there is an intrinsic difference between technological and social innovations.

More than seventy years ago, V. Bush, in his report to President Roosevelt, directed the pioneering spirit of the US towards exploring the "endless frontiers" of natural science research, hoping that this would promote social welfare: "The Government should accept new responsibilities for promoting the flow of new scientific knowledge and the development of scientific talent in our youth. These responsibilities are the proper concern of the Government, for they vitally affect our health, our jobs, and our national security. It is in keeping also with basic United States policy that the Government should foster the opening of new frontiers and this is the modern way to do it." (Bush, I945, paragraph I7). The belief in the central role of science and technologies is the still the basis for the contemporary innovation policies and our National Innovation Systems. 
Under this perspective, a social innovation is a new combination ${ }^{4}$ and/or a new configuration of social practices in certain areas of action or social contexts prompted by certain actors or constellations of actors in an intentional targeted manner with the goal of better satisfying or answering needs and problems than is possible on the basis of established practices. An innovation is, therefore, social to the extent that it, conveyed by the market or 'non/without profit', is socially accepted and diffused widely throughout society or in certain societal sub-areas, transformed depending on circumstances and ultimately institutionalized as new social practice or made routine. As with every other innovation, the 'new' does not necessarily mean 'good', but in this case is 'socially desirable' in an extensive and normative sense. According to the actors' practical rationale, social attributions for social innovations are generally uncertain (Howaldt \& Schwarz, 2010).

In this sense, social innovation can be "interpreted as a process of collective creation in which the members of a certain collective unit learn, invent and lay out new rules for the social game of collaboration and of conflict or, in a word, a new social practice, and in this process they acquire the necessary cognitive, rational and organizational skills" (Crozier \& Friedberg, I993, p. I9).

Social innovation is a key characteristic of the new innovation paradigm that also implies an innovation process opening up to society (Rosted, Kjeldsen, Bisgaard, \& Napier, 2009). Companies, technical schools, and research institutes are not the only relevant agents in the process of innovation. Citizens and customers no longer serve as suppliers for information about their needs (as in traditional innovation management); they make contributions to the process of developing new products to resolve problems.

In addition, Moulaert et al. (2013b, p. 2) emphasize that social innovation means innovation in social relations.

As such we see the term as referring not just to particular actions, but also to the mobilization-participation process and to the outcome of actions which lead to improvements in social relations, structures of governance, greater collective empowerment, and so on. ${ }^{5}$

4 The term relates to the Schumpeterian definition of innovation as a new combination of production factors.

$5 \quad$ Klein, Fontan, Harrisson and Lévesque (2013, p. 382). describe the development of the Québec Model as social innovation linked to social transformation. "From this standpoint, participative governance, co-production of services or activities, co-construction of public policies, as well as the plural character of the economy... represent important dimensions of social innovation", Thereby, they identify the 'economic turn' - "the fact that social movements have switched from merely demanding actions from other to proactive actions at the economic level" (Klein et al., 20I3, p. I82) - as an important source for social innovation. 
So social innovation should become "part of a new culture of empowerment" (EC - President Barroso) which is central to create appreciable social change. Thus, social innovations need to mobilise citizens to take an active part in innovation processes and thereby enhance society's generic innovative capacity (Bureau of European Policy Advisers, 20I0). This requires new models of governance in favour of self-organisation and political participation, allowing sometimes unexpected results through the involvement of stakeholders. This also requires interplay between actors, their networks, policy makers and the market on the one side, and processes in support of scaling-up and diffusion on the other.

In the face of the depth and development of change in modern societies and the rising dysfunction in established practice, social innovations are gaining greater importance, also in terms of economic factors, until technological innovations. They are not only necessary, but also can contribute proactively with regard to anticipated macro-trends, such as demographic developments or the effects of climate change "to modify, or even transform, existing ways of life should it become necessary so to do" (Giddens, 2005, p. I63). Social innovations are confronted with huge expectations of providing answers to wicked societal problems, given the fact that issues such as massive unemployment, the erosion of the social security system or the intensification of ecological risks cannot be overcome without implementing social innovation.

\section{SOCIAL INNOVATION AND SOCIAL CHANGE}

While culminating social and economic problems identified in public discourse are increasingly prompting a call for extensive social innovation, the relationship between social innovation and social change remains a largely under-explored area in the social sciences as well as government innovation policies. Phenomena of social change are consistently looked at in connection with technological innovation in techno-sociology and technical research in the prevailing paradigm of a social-technical system, but not from the perspective of an independent type of innovation that can be demarcated from technological innovations. This is inadequate in light of the declining functionality of the technology-oriented paradigm shaped by the industrial society.

Whereas - based mainly on Ogburn's theory - a specialised sociology of change has developed, with few exceptions social innovation as an analytical category is at best a secondary topic both in the classical and contemporary social theory approaches and concepts of social differentiation and social integration, social order and social development, modernisation, and transformation. Apart 
from a few exceptions (in particular Jessop, Moulaert, Hulgård, \& Hamdouch, 20I3; Mulgan, 20I2; Harrisson, 20I2; Howaldt \& Schwarz, 20I0; Hochgerner, 2009), the social sciences largely seem to refuse to "present and list as social innovations the relevant social changes" (Rammert, 20I0, p. 26) which they have discovered and studied. This is all the more astonishing given that Ogburn not only makes 'cultural lag' - the difference in the time it takes for the comparatively 'slow' non-material culture to catch up with the faster-developing material culture - his starting point and systematically differentiates between technological and social innovations (and inventions) as critical factors in social change. He also emphasises that use of the term 'inventions' is not restricted to technological inventions, but also includes social inventions such as the League of Nations.

Invention is defined as a combination of existing and known elements of culture, material and/or non-material, or a modification of one to form a new one... By inventions, we do not mean only the basic or important inventions, but the minor ones and the incremental improvements. Inventions, then, are the evidence on which we base our observations of social evolution (Ogburn, I969, p. 56-57).

Thus, Ogburn (1969, p. 56) is convinced that in the interplay of invention, accumulation, exchange and adaptation, he has discovered the basic elements of "cultural development" and hence - like Darwin for biological evolution - has developed a model to explain social evolution.

In the following, the debate mainly centres on the question whether social innovations are a prerequisite for, a concomitant phenomenon with, or consequence of technological innovations. Here, Ogburn (1969) is wrongly made the chief advocate of a technological interpretation of social change (Howaldt, Kopp, \& Schwarz, 2015).

Against the background of the emergence of a new innovation paradigm, it becomes more important to devote greater attention to social innovation as a mechanism of change residing at the micro and meso level. The reasons for this are obvious. Firstly, the shortcomings of older models of social change and an economically and technologically focused innovation model become increasingly apparent when dealing with the key social challenges. Secondly, new forms of governance and social self-management, of the "criticism that actually takes place in society" (Vobruba, 20I3, p. I60), of protest movements that aim to shape society (Marg, Geiges, Butzlaff, \& Walter, 2013) and new social practices in social life and related governance - understood as necessary social innovations are evidently becoming increasingly established. 
In the context of the broad social debate surrounding sustainable development and necessary social transformation processes (Geels \& Schot, 2007), the question of the relationship between social innovations and social change arises again: how can processes of social change be initiated which go beyond the illusion of centralist management concepts to link social innovations from the mainstream of society with the intended social transformation processes?

\section{TOWARDS A THEORETICALLY SOUND CONCEPT OF SOCIAL INNOVATION - THE PROJECT SI- DRIVE}

\subsection{OBJECTIVES AND ANALYTICAL CONCEPT}

Answering the need to describe social innovation in all its diversity, to develop robust models for the creation, roll out and diffusion of social innovations, and to better understand the relation between social innovation and social change, the global research project SI-DRIVE, funded within the 7 th Framework Programme of the European Commission ${ }^{6}$ looks at the theoretical concepts, areas of empirical research and observable trends in the field of social innovation on both European and global scales. SI-DRIVE has mapped social innovation projects and initiatives all over the world. I005 cases have been collected with 25 project partner institutions contributing to the sample. For the first time, socially innovative projects and initiatives around the world have been analysed and compared in such quantities (Howaldt, Schröder, Kaletka, Rehfeld, \& Terstriep, 20ı6).

The I005 cases are the result of an expert based selection. Social innovation experts from all world regions, all of them either SI-DRIVE project partners or advisory board members, were asked to identify cases which meet the criteria of the working definition of social innovation. These cases could be in different stages of the innovation process, from ideation, implementation, imitation/ diffusion up to the stage where the solution has already been institutionalized. A survey template consisting of open and structured questions was developed for the data collection of all cases. A case is defined as follows: a case is what the experts define as a relevant social innovation project/initiative; a case has to show novelty of the social practice and first diffusion in society. The key objectives of the empirical exercise are:

SI-DRIVE involves I5 partners from I2 EU Member States and Io from other parts of the world. The approach adopted carefully interlinks the research process to both the complexity of the topic and the project workflow. The project will explicitly link to and cooperate with existing EU and (international) projects, dissemination platforms and networks. 
- to determine the nature, characteristics and impacts of social innovation as key elements of a new paradigm of innovation (strengthen the theoretical and empirical base of social innovation as part of a wider concept of innovation that thoroughly integrates social dimensions);

- to map, analyse and promote social innovations in Europe and world regions to better understand and enable social innovations and their capacity for changing societies;

- to identify and assess success factors of social innovation in seven particular policy $\operatorname{areas}^{7}$, supporting reciprocal empowerment in various countries and social groups to engage in social innovation for development, working towards Europe 2020 targets and sustainable development (e.g. Millennium Development Goals - MDG); and

- to undertake future-oriented policy-driven research, analyse barriers and drivers for social innovation; develop tools and instruments for policy interventions (social innovation experimentation, incubation, 'Social Innovation Manual').

There are five key dimensions of social innovation that fundamentally affect the potential of social innovations, their scope, and their impact. They are:

I. concepts of social innovation including the relationship to technology and business innovation;

2. objectives and social demands, societal challenges and systemic changes that are addressed;

3. actors, networks and governance (including the role of social entrepreneurship, networks, user involvement) of social change and development;

4. process dynamics;

5. resources, capabilities and constraints including finance and regulations of the finance industries, human resources, empowerment.

The theoretical and empirical research of SI-DRIVE is framed around these five key dimensions. During the first phase of the project, the theoretical analysis provided a general depiction of how social innovation resonates within the wider frameworks of existing innovation theory and research, the concepts and perceptions of social change, and of societal and policy development. The five key dimensions of social innovation are essential in assessing the relations identified. Subsequently, empirical research has been applied to classify what can be observed

The seven defined policy areas of social innovation in SI-DRIVE are education, employment, environment and climate change, energy, transport and mobility, health and social care, and poverty reduction. 
in social reality into a typology of social innovation. Empirical research, with the global mapping of social innovation initiatives as its first phase, comprises seven policy areas and eight cultural/world regions. SI-DRIVE analyses the differences and commonalities between social innovations in these areas to understand how social innovations develop and scale under different conditions and in relation to the cross-cutting themes (e.g. empowerment, human resources, knowledge).

\section{FIGURE I}

\section{THE KEY DIMENSIONS OF SOCIAL INNOVATION}

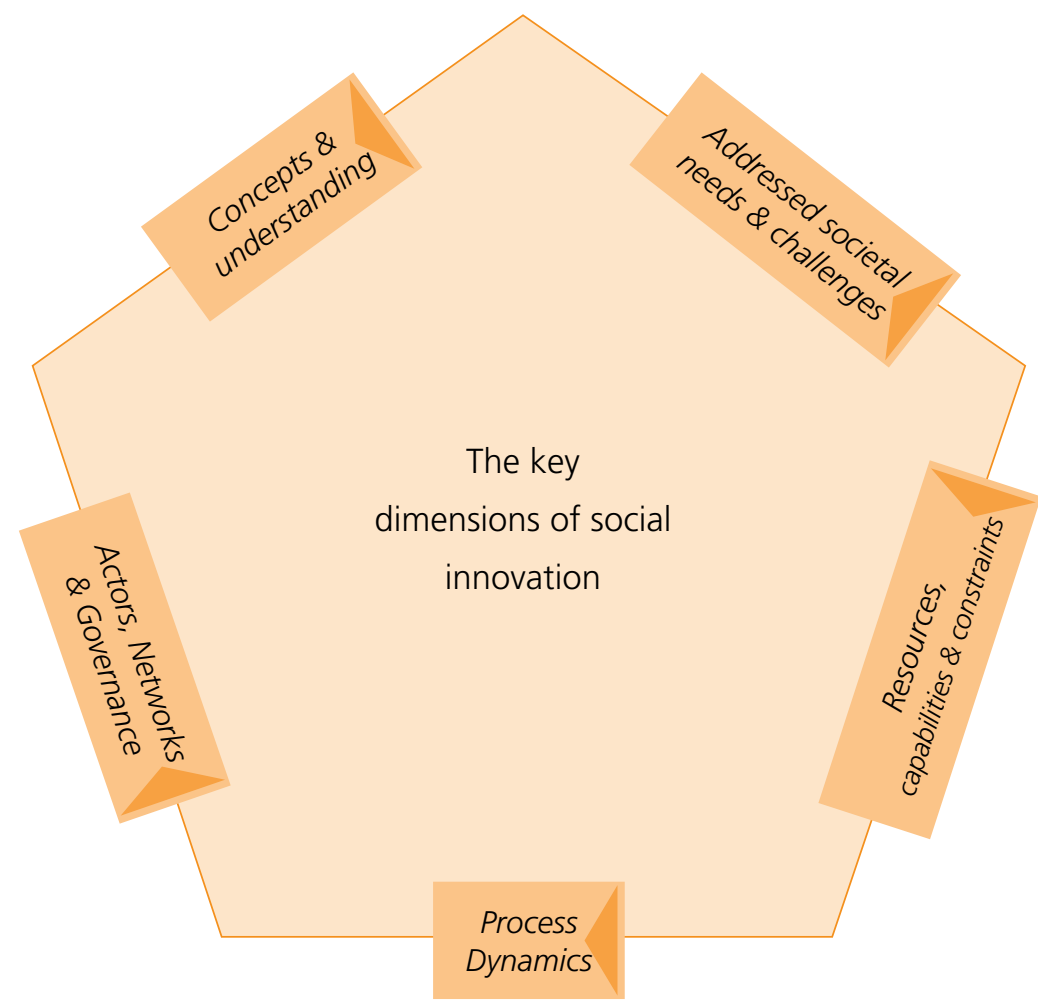

Source: Howaldt, Butzin, Domanski and Kaletka (20I4).

\subsection{PRELIMINARY RESULTS OF THE GLOBAL MAPPING OF SOCIAL INNOVATION INITIATIVES}

As shown above, a database of Io05 cases has been created for the global mapping, covering about 80 countries from all world continents and addressing seven policy fields. To better define what is a social innovation case and to reduce 
the immense variety of social innovation categories, we applied a methodology distinguishing between so-called practice fields and initiatives. A practice field is general type or summary of initiatives expressing some main characteristics common to different initiatives (e.g. micro-credit systems, car sharing) in relation to single initiatives with a concrete implementation of a solution responding to social demands, societal challenges or systemic change (e.g. Grameen Bank, which lends micro-credits to poor farmers for improving their economic conditions, concrete car sharing initiatives). In the following, we present the results of the first phase of the global mapping of social innovation initiatives according to the five key dimensions of social innovation.

\subsubsection{Concepts and understanding of social innovation}

The concept and understanding of social innovation are depicted so far by a growing importance worldwide on the one hand and by an unclear understanding and an unexploited potential on the other hand. A growing number of brand new as well as adopting initiatives become a visible reaching impact in short term, diverse established and new practice fields appear connected with and affecting diverse policy fields causing innovation streams embedded in networks or umbrella organisations, social movements or policy programs. The mapping hence confirms the assumption that there is a need for a concept of social innovation that would address different sectors, various types of partners, policy fields and cross-cutting themes as well as aspects of empowerment, user involvement, and human resources - stressed as a driving force and necessary precondition of and for social innovations.

\subsubsection{Objectives: Social Demands, Societal Challenges, and Systemic Change Addressed}

A high diversity of addressed social needs and societal challenges appear in the seven policy fields, while different societal levels on which output may be generated become evident. The need to respond to a specific societal challenge or a local social demand are by far the main motivation and trigger for starting, initiating and running a social innovation. More than $60 \%$ of the initiatives started from this perspective. These objectives are more relevant than having an inspiring new idea ( $28 \%)$, a policy incentive like a policy programme or strategy (I8\%) or a social movement focusing on specific issues (15\%). The possibility of taking advantage of new technologies for tackling social problems is a first motivation or trigger for $23 \%$ of the cases. Most initiatives do not address one societal level alone, but rather different combinations. At the same time, the societal level 
addressed by the initiatives is varying in the different policy fields with a strong focus on social needs in the most of the policy fields, except for Transport and Mobility and Energy Supply which both have a stronger orientation towards societal challenges. Although systemic change plays a minor role in all policy fields, differences between policy fields are considerable.

\subsubsection{Resources, Capabilities, and Constraints}

Here, one of the key tasks of the global mapping was to find out which are the human and financial resources that social innovations rely on. As the survey reveals, more than $60 \%$ of the initiatives with regular paid staff have up to ten employed people, and more than one-third are supported by more than ten volunteers. About half of the initiatives are supported by up to 5 external experts and advisers. The initiatives referring to a high budget are mainly funded by national public money and economic return. Low budget initiatives (up to I0.000 Euros) are mainly dependent on partner contributions, foundations and philanthropy capital and donations from single persons or companies. Initiatives with a higher budget (above I million Euros) also are more active in transfer (above 70\%), done mainly by the project partners. There is a wide range and mixture or combination of funding sources (internal, public, private, civil society) the initiatives are based on. In Europe, there is higher orientation, and therefore dependency from (European, national and regional) public funding and initiative internal (co-) funding (participant fees and own contributions) while in non-European countries donations and foundations are the main (worldwide) players for funding.

Funding is by far the main challenge, also due to the fact there is still no systemic support of social innovation compared with technological development environments. Against the background that empowerment, human resources, and knowledge are the main cross-cutting themes the appointed lack of personnel and knowledge gaps could be seen as relevant barriers as well, especially because the SI-DRIVE's 'Critical Literature Review' on theoretical approaches to social innovation (Howaldt, Butzin, Domanski, \& Kaletka, 20I4) stated transfer of knowledge as a key component for the diffusion of social innovations: taking both together these human resources handicaps are hindering about one of three initiatives. Legal restrictions and missing political supports are the third block of barriers, relevant for $14 \$-\mathrm{I} 7 \%$ of the cases.

\subsubsection{Actors, Networks, and Governance}

A broad range of actors is involved in the mapped social innovation initiatives. Being engaged in approximately $46 \%$ of the mapped initiatives each, NPOs/ 
NGOs and public bodies can be considered as key partners, followed by private companies (37\%). Engagement of social enterprises, individuals, networks and groups, foundations as well as research organisations clearly lags behind, with shares ranging from I3 to $15 \%$. User involvement could be detected in about $46 \%$ of the mapped cases. The most common form of involvement is the provision of knowledge (named in $40 \%$ of the cases), usually occurring throughout the social innovation process in the form of dialogues, feedback, testing and experimentation, suggestions for further improvement as well as tutoring. Users as solution providers rank second ( $26 \%$ ), and users as co-creators rank third (15\%).

Regarding the role of networks, the survey shows that almost a half of the mapped initiatives (49\%) have been developed and implemented by networks consisting of 3 or more partners, while slightly more than a half of the initiatives $(51 \%)$ did not involve such partnerships as the initiator developed and implemented the solution alone (35\%) or just with I additional partner (I6\%). Taking a closer look at those initiatives with network collaboration reveals that the majority of social innovations were developed by rather small networks of 3 to 6 actors $(38 \%)$, whereas additional $9 \%$ of initiatives elaborated solutions in a network consisting of 7 to II actors. Larger networks of I2 to I9 partners are rather an exception (2\%).

Finally, in terms of governance of social innovations, the survey has revealed that policy programmes are the dominant framework in which the mapped social innovation initiatives are embedded in, except for the policy field Poverty Reduction and Sustainable Development where umbrella organisation show to be most relevant.

\subsubsection{Process Dynamics}

Regarding the process dynamics, the data reveal that $53 \%$ of the mapped initiatives state to have already reached the impact stage and another $36 \%$ are in the implementation phase, $6 \%$ are in the testing phase, $3 \%$ in the phase of the invention, and $2 \%$ in the phase of ideation or inspiration. With regard to the novelty of social innovations, nearly $50 \%$ of the solutions have originally been developed by the partners, while the remaining 50\% have been adopted from other initiatives. This gives us an important indication that imitation, learning, and adaption are supposed to play a role in such dynamics. The regional comparison of the initiatives' innovative character suggests that in Eastern Europe social learning triggered by the adaption of solutions from other social innovations plays a crucial role while in Northern and Southern Europe as well as in Non-EU countries completely new solutions outweigh modified and improved initiatives.

The mapping shows that $90 \%$ of the initiatives are scaling in one or the other way, whereby increasing the target group is with a share of $70 \%$ by far the 
most applied scaling mechanism. At some distance, network extension ranks second with a share of $49 \%$. Closely related to scaling is the transfer of solutions, which also reflects the dynamics of social innovation processes. The analysis reveals that $66 \%$ of initiatives transferred their solution in one or the other way, hence showing that transfer is a common practice of the mapped cases. From a spatial perspective, however, it becomes evident that most initiatives remain local $(4 \mathrm{I} \%)$, although more than a third of initiatives achieves transfer at the national level. In nearly half of the total of the cases, the transfer is done by project partners and another half by external partners.

These results provide valuable insights into the diversity of social innovation around the world. Due to the quantitative approach of the first empirical phase from which the results were drawn, the relation between social innovation and social change cannot yet be addressed in detail. This will be a focus of the second empirical phase of SI-DRIVE in which 70 in-depth case studies will be conducted. In this upcoming phase, the development of social innovation cases as part of a wider and connected practice field will be analysed. On this level of practice fields as connected bundles of social innovations the relation to social change is expected to become clearer also from an empirical perspective.

\section{THE SIGNIFICANCE OF SOCIAL THEORY - A RECOURSE TO GABRIEL TARDE}

Recourse to Tarde, the long-forgotten classic exponent of sociology of innovation, is helpful in gaining a better theoretical understanding of the relationship between social innovations and social change. His achievement consists in explaining social change 'from the bottom up', and not objectivistically, like Durkheim, 'from the top down,' in terms of social facts and structures (Gilgenmann, 2010). Tarde's contribution to the micro-foundation of a sociology of innovation can be used to assist in developing a concept of social innovation as a social mechanism of change residing at the micro and meso level. This seems all the more necessary given that Tarde's social theory - with a view to its implications and potentials for the analysis of innovation - has not been systematically explored until now.

Tarde's theory allows us to widen a perspective which was narrowed to economic and technological innovations by Schumpeter, and after him by the sociology of technology, to include the wide variety of social innovations. At the same time, this reveals the blind spots of an economically narrow view. Because Tarde places the laws of the practices of imitation at the centre of his theory of social development, the associated micro foundation of social phenomena provides 
vital input into an integrative theory of innovation. It enables us to discover how social phenomena, conditions, and constructs come into being and transform. The key to this is to meticulously trace social inventions and innovations as well as the associated social practices of their imitation.

This character of Tarde's social theory, referring strongly to the social prerequisites for invention and imitation, is also underlined by the fact that unlike Schumpeter, for whom the innovator in the social figure of the entrepreneur is the focus of interest, for Tarde it is inventions which are understood to be the central "driver" of social development. For Tarde, there are many small inventions and ideas "which were difficult or easy to arrive at and mostly went unnoticed at the time of their arising, which therefore are usually almost exclusively inglorious and nameless" (Tarde, 2009, p. 26).

These countless and nameless inventions and discoveries change society, and its practices through equally countless acts of imitation, and only as a result do they become a true social phenomenon. "In the realm of the social, everything takes place as invention and imitation, with imitation forming the rivers and inventions the mountains" (Tarde, 2009, p. 27). For Tarde, imitation is the central mechanism of social reproduction and social change. "All similarities of social origin that belong to the social world are the fruits of some kind of imitation, be it the imitation of customs or fashions through sympathy or obedience, instruction or education, naïve or carefully considered imitation" (Tarde, 2009, p. 38).

Since imitation always involves variation as well, imitations also simultaneously transform innovations into social structures and practices. Added to this, there are individual initiatives and rebellions against prevailing morals, customs, rules - interruptions or crossings of imitation streams - which are transferred and imitated from person to person, leading to social innovations.

Therefore, Tarde can also be used to bring about an important shift in perspective. Rather than constantly producing new individual inventions, it seems more meaningful to creatively reconfigure the potentials of existing inventions through social practice. "The qualities that in any age and any land make a man superior are those which make him better able to understand the discoveries already made and exploit the inventions already devised" (Tarde, 2009, p. 25I). In this context, the wealth of a nation for Tarde is rooted in its ability to "use the knowledge of its time in a particular way" (Tarde, 2009, p. 254). If, like Tarde, one seeks to explain a situation from the imitation practices of people, the specific cultural frameworks need to be decoded.

With the shift in perspective from inventions to social practices of imitation, the key question in the context of diffusion is how new social practices come into being from the imitation of social practices. The concept of imitation 
underpins an understanding of innovation which focuses on social practices. Only these can be imitated. Practices of organisation, consumption, production and so forth become the central object of Tarde (2009)'s conception of imitation. This includes the manufacturing and consumption of technological artefacts. The imitative spread of social ideas or initiatives tends to combine with other inventions to form increasingly complex and more widely acting social innovations. Imitation always comprises variation as well, and to this extent imitations constantly bring innovations into social structures and constructs.

If we follow Tarde (2009) in pointing out the social embeddedness of any invention in a dense network of imitation streams, then social innovations are first and foremost ensemble performances, requiring interaction between many actors. As the opening of the innovation process to society is a key characteristic of the new innovation paradigm (Howaldt \& Kopp, 20I2), there is an accompanying increase in the experimental processes which take place not only in the separate world of scientific laboratories but also in society. Social innovations and their actors, who critically, exploratively and experimentally depart from the prevailing 'mental maps', the established rules, routines, pathways and models in politics, business and society - such as the economisation of all life's areas and an inevitable link between prosperity and growth (Jackson, 20I2) - who call these into question and in a 'competition of ideas' lead the way to changed, alternative social practices and lifestyles, are the basis and relevant drivers of transformative social change (e.g. Jonker, 20I2).

The conception of social innovation founded in social theory, therefore, focuses on the interfaces between the self-referencing social sectors of government, business, and civil society, which are distinct and largely shielded from one another, on their respective rationales of action and regulatory mechanisms, and on the associated problems and limited problem-solving capacities. Regarding the governance question of how these interfaces should be reconfigured, established patterns of control and coordination are added, expanded and reforged via aspects such as self-organisation, intersectoral cooperation, networks and new forms of knowledge production. The associated processes of "cross-sector fertilisation" (Phills, Deiglmeier, \& Miller, 2008, p. 40) and convergence of sectors (Austin, Gutierrez, Ogliastri, \& Reficco, 2007) increasingly enable a kind of blended value creation (Emerson, 2003) while at the same time promoting a "moralisation of markets" (Stehr, 2007). Such cross-fertilisation and convergence processes require and enable far-reaching social innovations, which set in motion and spur the necessary blending of boundaries.

Changing social practices are generally based on drawn-out, contingent and self-managing processes which, as Tarde points out, are subject to their own "laws" - the laws of imitation. Previous attempts to "manage" such processes 
through policy have generally proven to be decidedly difficult. A comprehensive innovation policy, which in addition to supporting new technologies also focuses on social innovations and enabling actors "to suspend established routines and patterns, as only then can new ideas and behaviours thrive" (Adolf, 20I2, p. 40), on the necessary "freedom" to do this and the opportunities "to share objectified and personal (implicit) knowledge" (Adolf, 20I2, p. 4I), is only in its infancy and requires above all a deeper understanding of the principles and modes of action of social innovations.

One of the key tasks in this regard is a necessary redefinition of the relationship between policy and the "new power of the citizenry" (Marg et al., 2013), civil society engagement, the many and diverse initiatives and movements "for the transformation of our type of industrial society" (Welzer, 2013, p. I87). "A central element here is to enable citizens [in the sense of empowerment - authors' note] to share in responsibility for the future, which should not be equated with personal responsibility in the neoliberal sense" (Rückert-John, 20I3, p. 29I).

\section{CONCLUSIONS}

A sociological innovation theory must, therefore, examine the multiple and manifold imitation streams and decode the principles and laws they follow. From this perspective, the focus is always on social practice, since it is only via social practice that the diverse inventions, etc. make their way into society and thus become the object of acts of imitation. Social practice is a central component of a theory of transformative social change, in which the wide variety of everyday inventions constitute stimuli and incentives for reflecting on and possibly changing social practices. It is only when these stimuli are absorbed, thereby leading to changes in existing social practices which spread through society and construct social cohesion via acts of imitation, that they drive social transformation. Thus new perspectives open up on an understanding of innovation which adequately captures the diversity of innovations in society.

The great challenge for contemporary innovation policy lies in exploiting these potentials. Just as the conditions to explore the potentials of the natural sciences and to make them usable for society were created through a systematic innovation policy in the middle of the last century, at the beginning of the 2Ist century we need just as great a pioneering spirit in the search for new social practices that enable us to secure the future and allow people to live "a richer and more fulfilled human life" (Rorty, 2008, p. I9I).

The observations made above point out that increased attention has to be paid to social innovation to develop the potential for new social practices beyond 
the hitherto dominant growth ideology. To this extent, a new model for innovation policy is required that shifts its focus from technologies to social innovations and systemic solutions and a corresponding empowerment of actors, thus complementing the new conceptual understanding of social innovation with a consistent social policy.

\section{INOVAÇÃO SOCIAL: EM DIREÇÃO A UM NOVO PARADIGMA DE INOVAÇÃO}

\section{RESUMO}

Objetivo: Perante o cenário de paradoxos claros e a confusão em políticas de inovação vigentes, os contornos de um novo paradigma de inovação, como elaborado neste trabalho, estão se tornando visíveis, permitindo que a inovação social cresça em importância.

Originalidade/lacuna/relevância/implicações: No entanto, as pesquisas sobre inovação ainda possuem lacunas a respeito de uma análise sustentada e sistemática sobre inovação social, suas teorias, características e impactos. O objetivo deste trabalho é focalizar, sob um enfoque teórico, o conceito de inovação social como uma condição prévia para uma teoria integrada da inovação sóciotecnológica na qual a inovação social é mais do que um apêndice da inovação tecnológica.

Principais aspectos metodológicos: $\mathrm{O}$ artigo apresenta os primeiros resultados empíricos do projeto de investigação global "SI-DRIVE: Social Innovation - Driving Force of Social Change" e introduz os principais achados de um mapeamento global de iniciativas de inovação social. Esse mapeamento quantitativo baseia-se em I.005 iniciativas de inovação social.

Síntese dos principais resultados: O mapeamento sublinha a ampla gama de atores envolvidos nas iniciativas mapeadas e, desse modo, confirma a necessidade de um conceito trans-setorial de inovação social. Revela uma alta diversidade de necessidades sociais e desafios societais, dirigidos pelas iniciativas, bem como uma alta dependência de redes. Os resultados também mostram que 90\% das iniciativas estão em crescimento.

Principais considerações/conclusões: Finalmente, com base nestes resultados empíricos e mediante a utilização da teoria social de Gabriel Tarde, é possível ampliar a perspectiva que foi elaborada para inovações econômicas e tecnológicas por Schumpeter e, posteriormente, pela Sociologia da Tecnologia, visando incluir inovações sociais em toda a sua diversidade. 


\section{PALAVRAS-CHAVE}

Inovação social. Novo paradigma de inovação. Mudança social. Mapeamento global. Gabriel Tarde.

\section{INNOVACIÓN SOCIAL: HACIA UN NUEVO PARADIGMA DE INNOVACIÓN}

\section{RESUMEN}

Objetivo: En el contexto de las paradojas y la confusión en las políticas de innovación existentes, los contornos de un nuevo paradigma de la innovación, elaborada en este trabajo, se están convirtiendo en visibles, permitiendo la innovación social, crece en importancia.

Originalidad/laguna/relevancia/implicaciones: Sin embargo, la investigación sobre la innovación aún tiene deficiencias con respecto a un análisis sostenido y sistemático de la innovación social, sus teorías, características e efectos. El objetivo de este estudio es centrarse, desde una perspectiva teórica, el concepto de innovación social como requisito previo para una teoría integrada de la innovación socio-tecnológico en el que innovación social es más que un apéndice de la innovación tecnológica.

Principales aspectos metodológicos: El artículo presenta los primeros resultados empíricos del proyecto mundial de investigación "SI-DRIVE: Social Innovation - Driving Force of Social Change" y presenta las principales conclusiones de una asignación global de las iniciativas de innovación social. Este mapeo cuantitativo se basa en r.005 iniciativas la innovación social.

Síntesis de los principales resultados: El mapa pone de relieve la amplia gama de actores que participan en las iniciativas asignadas y, por lo tanto, confirma la necesidad de un concepto sectorial transversal de la innovación social. Revela una gran diversidad de necesidades sociales y retos de la sociedad, impulsada por las iniciativas y una alta dependencia de las redes. Los resultados también muestran que el 90\% de las iniciativas están creciendo.

Principales consideraciones/conclusiones: Por último, sobre la base de estos resultados empíricos a través de la utilización de la teoría social de Gabriel Tarde, es posible ampliar una perspectiva que está diseñado para las innovaciones tecnológicas y económicas por Schumpeter y más tarde por la Sociología de la Tecnología con el fin de incluir las innovaciones sociales en toda su diversidad. 


\section{PALABRAS CLAVE}

Innovación social. Nuevo paradigma de la innovación. Cambio social. Cartografía mundial. Gabriel Tarde.

\section{REFERENCES}

Adolf, M. (2012). Die Kultur der Innovation. Eine Herausforderung des Innovationsbegriffs als Form gesellschaftlichen Wissens. In R. M. Hilty, T. Jaeger \& M. Lamping (Eds.). Herausforderung Innovation. Eine interdisziplinäre Debatte (pp. 25-43). Berlin, Heidelberg: Springer.

Austin, J. E., Gutierrez, R., Ogliastri, E., \& Reficco, E. (2007). Capitalizing on Convergence. Stanford Social Innovation Review, 5(4), 24-3I.

Bureau of European Policy Advisers - Bepa (2010). Empowering people, driving change: Social innovation in the European Union. Luxembourg: Publication Office of the European Union.

Blättel-Mink, B. (2006). Kompendium der Innovationsforschung. Wiesbaden: VS Verlag.

Bruland, K., \& Mowery, D. C. (2005). Innovation through time. In J. Fagerberg, D. C. Mowery \& R. R. Nelson (Eds.). The Oxford Handbook of Innovation (pp. 349-379). New York: Oxford University Press.

Bush, V. (I945). Science The Endless Frontier. A Report to the President by Vannevar Bush, Director of the Office of Scientific Research and Development, July 1945. Retrieved August 8, 20I6, from https:// www.nsf.gov/od/lpa/nsf5o/vbushi945.htm.

Crozier, M., \& Friedberg, E. (1993). Die Zwänge kollektiven Handelns - Über Macht und Organisation. Frankfurt: Hain.

Emerson, J. (2003). The blended value map. Integrating Social and Financial Returns. California Management Review, 45(4), 35-51.

Fagerberg, J., Mowery, D. C., \& Nelson, R. R. (Eds.). (2005). The Oxford Handbook of Innovation. New York: Oxford University Press.

Franz, H.-W., Hochgerner, J., \& Howaldt, J. (Eds.). (2012). Challenge social innovation. Potentials for Business, Social Entrepreneurship, Welfare and Civil Society. Berlin, New York: Springer.

Geels, F. W., \& Schot, J. (2007). Typology of sociotechnical transition pathways. Research Policy, 36(3), 399-4I7.

Giddens, A. (1995). Die Konstitution der Gesellschaft. Grundzüge einer Theorie der Strukturierung. Frankfurt, New York: Campus.

Gilgenmann, K. (2010). Gabriel Tarde oder die Erfindung und Nachahmung eines Klassikers. Soziologische Revue, 33(3), 26I-286.

Gillwald, K. (2000). Konzepte sozialer Innovation. Querschnittsgruppe Arbeit und Ökologie. Wissenschaftszentrum Berlin für Sozialforschung. Retrieved August I2, 20I6, from http://bibliothek.wzb. eu/pdf/2000/poo-519.pdf.

Harrisson, D. (2OI2). Social Innovation: What Is Coming Apart and What Is Being Rebuilt? In H.-W. Franz, J. Hochgerner \& J. Howaldt (Eds.). Challenge Social Innovation. Potentials for Business, Social Entrepreneurship, Welfare and Civil Society (pp. 73-82). Berlin, New York: Springer. 
Harrisson, D., Bourque, R., \& Széll, G. (2009). Social Innovation, Economic Development, Employment, and Democracy. In D. Harrisson, G. Széll \& R. Bourque (Eds.). Social Innovation, the Social Economy and World Economic Development. Democracy and Labour Rights in the Era of Globalization (pp. 7-I5). Frankfurt: Peter Lang.

Hochgerner, J. (20I2). New Combinations of Social Practices in the Knowledge Society. In H.-W. Franz, J. Hochgerner \& J. Howaldt (Eds.). Challenge Social Innovation. Potentials for Business, Social Entrepreneurship, Welfare and Civil Society (pp. 87-I05). Heidelberg, New York, Dordrecht, London: Springer.

Hochgerner, J. (2009). Innovation processes in the dynamics of social change. In J. Loudin \& K. Schuch (Eds.). Innovation cultures. Challenge and learning strategy (pp. I7-45). Prague: Filosofia.

HOWALDT, J. Social Innovation: towards a new innovation paradigm. In: COLLOQUE INTERNATIONAL DU CRISES. La transformation sociale par 1' innovation sociale, 4., 20I4, Montréal. Proceedings... Montréal: Hôtel Gouverneur Place Dupuis, 2014.

Howaldt, J., Butzin, A., Domanski, D., \& Kaletka, C. (20I4). Theoretical Approaches to Social Innovation - A Critical Literature Review. Retrieved August I2, 20I6, from http://www.si-drive.eu/wp-content/uploads/20I4/II/DI_I-Critical-Literature-Review_final.pdf.

Howaldt, J., \& Kopp, R. (20I2). Shaping Social Innovation by Social Research. In H.-W. Franz, J. Hochgerner \& J. Howaldt (Eds.). Challenge Social Innovation. Potentials for Business, Social Entrepreneurship, Welfare and Civil Society (pp. 43-56). Heidelberg, New York, Dordrecht, London: Springer. Howaldt, J., Kopp, R., \& Schwarz, M. (2015). Social Innovations as Drivers of Social Change Exploring Tarde's Contribution to Social Innovation Theory Building. New Frontiers in Social Innovation Research (pp. 29-5I). Basingstoke: Palgrave Macmillan UK.

Howaldt, J., Schröder, A., Kaletka, C., Rehfeld, D., \& Terstriep, J. (2016). Mapping the World of Social Innovation: A Global Comparative Analysis across Sectors and World Regions. Retrieved August I2, 20I6, from http://www.si-drive.eu/wp-content/uploads/20I6/07/SI-DRIVE-DI-4-Comparative-Analysis-20ı6-०8-i5-final.pdf.

Howaldt, J., \& Schwarz, M. (20I0). Social Innovation: Concepts, research fields, and international trends. Retrieved August I2, 20I6, from http://www.sfs-dortmund.de/odb/Repository/Publication/ Doc\%5Ci289\%5CIMO_Trendstudie_Howaldt_Schwarz_englische_Version.pdf.

Jackson, T. (2012). Wohlstand ohne Wachstum. Leben und Wirtschaften in einer endlichen Welt. Bonn: Bundeszentrale für Politische Bildung.

Jenson, J., \& Harrisson, D. (2013). Social innovation research in the European Union. Approaches, findings and future directions. Brussels: European Comission.

Jessop, B., Moulaert, F., Hulgård, L., \& Hamdouch, A. (2013). Social Innovation research: a new stage in innovation analysis?. In F. Moulaert, D. MacCullam, A. Mehmood \& A. Hamdouch (Eds.). The International Handbook on Social Innovation. Collective action, social learning and transdisciplinary research (pp. II-I30). Cheltenham: Elgar.

Jonker, J. (2012). Sustainable Thinking and Acting. An inspirational book for shaping our common future. Deventer: Kluwer.

Klein, J.-L., Fontan, J.-M., Harrisson, D., \& Lévesque, B. (2013). The Québec Model: a social innovation system founded on cooperation and consensus building. In F. Moulaert, D. MacCullam, A. Mehmood \& A. Hamdouch (Eds.). The International Handbook on Social Innovation. Collective action, social learning and transdisciplinary research (pp. 37I-383). Cheltenham: Elgar.

Kuhn, T. S. (I996). Die Struktur wissenschaftlicher Revolutionen. Frankfurt: Suhrkamp. 
Malerba, F. (2005). Sectoral Systems: How and Why Innovation Differs across Sectors. In J. Fagerberg, D. C. Mowery \& R. R. Nelson (Eds.). The Oxford Handbook of Innovation (pp. 380-406). New York: Oxford University Press.

Marg, S., Geiges, L., Butzlaff, F., \& Walter, F. (Eds.) (2013). Die neue Macht der Bürger. Was motiviert Protestbewegungen? BP-Gesellschaftsstudie. Bonn: Bundeszentrale für Politische Bildung.

Moulaert, F., MacCallum, D., Mehmood, A., \& Hamdouch, A. (Eds.) (20I3a). The International Handbook on Social innovation. Collective action, social learning and transdisciplinary research. Cheltenham: Elgar.

Moulaert, F., MacCallum, D., Mehmood, A., \& Hamdouch, A. (2013b). General introduction: the return of social innovation as a scientific concept and a social practice. In F. Moulaert, D. MacCullam, A. Mehmood \& A. Hamdouch (Eds.). The International Handbook on Social Innovation. Collective action, social learning and transdisciplinary research (pp. I-8). Cheltenham: Elgar.

Moulaert, F., Martinelli, F., Swyngedouw, E., \& Gonzalez, S. (2005). Towards Alternative Model(s) of Local Innovation. Urban Studies 42(II), I669-I990.

Mulgan, G. (20I2). Social Innovation Theories: Can Theory Catch Up with Practice? In H.-W. Franz, J. Hochgerner \& J. Howaldt (Eds.). Challenge Social Innovation. Potentials for Business, Social Entrepreneurship, Welfare and Civil Society (pp. 19-42). Heidelberg/New York/Dordrecht/London: Springer.

Ogburn, W. F. (1969). Erneute Betrachtung des Problems der sozialen Evolution. In H. Maus \& F. F. (Hrsg.), Soziologische Texte, Band 56: William F. Ogburn. Kultur und Sozialer Wandel. Ausgewählte Schriften. Berlin: Luchterhand. 50-67.

Phills, Jr., J. A., Deiglmeier, K., \& Miller, D. T. (2008). Rediscovering Social Innovation. Stanford Social Innovation Review 6(4), 33-43.

Rammert, W. (20I0). Die Innovationen in der Gesellschaft. In J. Howaldt \& H. Jacobsen (Eds.). Soziale Innovation. Aufdem Weg zu einem postindustriellen Innovations paradigma (pp. 2I-52). Wiesbaden: VS Verlag für Sozialwissenschaften.

Rorty, R. (2008). Philosophie als Kulturpolitik. Frankfurt: Suhrkamp.

Rosted, J., Kjeldsen, C., Bisgaard, T., \& Napier, G. (2009). New Nature of Innovation. Copenhagen: OECD.

Rückert-John, J. (20I3). Die Nachhaltigkeit der Debatte um soziale Innovationen - Innovationsschub für den nachhaltigen Wandel. In J. Rückert-John (Ed.). Soziale Innovation und Nachhaltigkeit. Perspektiven sozialen Wandels (pp. 289-307). Wiesbaden: Springer.

Schumpeter, J. A. (1964). Theorie der wirtschaftlichen Entwicklung. Berlin: Duncker \& Humblot.

Stehr, N. (2007). Die Moralisierung der Märkte. Eine Gesellschaftstheorie. Frankfurt: Suhrkamp.

Tarde, G. (2009). Die Gesetze der Nachahmung. Frankfurt: Suhrkamp.

Vienna Declaration (20II). The Most Relevant Topics in Social Innovation Research. Concluding resolution provided by the conference "Challenge Social Innovation. Innovating Innovation by Research 100 Years after Schumpeter”. Retrieved August I2, 20I6, from http://www.net4society.eu/_media/ Vienna-Declaration_final_ioNov2oiı.pdf.

Vobruba, G. (2013). Soziologie und Kritik. Soziologie 42(2), I47-I68.

Von Tunzelmann, N., \& Acha, V. (2005). Innovation in “Low-Tech” Industries. In J. Fagerberg, D. C. Mowery \& R. R. Nelson (Eds.). The Oxford Handbook of Innovation (pp. 407-432). New York: Oxford University Press.

Welzer, H. (2013). Selbst denken. Eine Anleitung zum Widerstand. Frankfurt: S. Fischer Verlag. 